\title{
3 次元射出成形 CAE システムの開発
}

中 亮 ${ }^{* 1} \cdot$ 坂 場 克 哉*1 $\cdot$ 澤 田 聡*2 $^{*}$ 結 城 高 志 ${ }^{* 1}$ 須賀 康 雄 ${ }^{* 3}$

\section{1.はじめに}

近年, IT 技術の著しい進歩に呼応して, 樹脂製品設計 や金型設計の分野でもデジタルエンジニアリングの活用が 急速に進んでいる．特に韓国や台湾，中国において見られ るように, 3 次元 $\mathrm{CAD} / \mathrm{CAM} / \mathrm{CAE}$ 技術を基本とした製 品開発の仕組みを構築することによって競争力の源とし, 短期間で品質の良い製品を低コストで開発・生産する企業 が台頭してきている. 国内に打いても自動車, 電機, 雑貨 などあらゆる分野で 3 次元デー夕をベースにした製品開発 が定着してきた. 3 次元情報をいかに有効活用して, 高品 質な製品や金型の効率的な設計開発につなげていけるか, という点が大きな課題となっている.

射出成形 CAE は 1970 年代から実用が始まった。当初 は樹脂の流路をあらかじめ予測し, 2 次元に展開して充填 の進行や圧力を求める展開法が用いられていたが, やがて 有限要素法などの数值離散化手法が取り入れられ, シェル 構造モデルによって複雑な形状が解析できるようになった。 シェル構造による形状表現は, 肉厚変更やリブ追加といっ た検討が簡単に行えるメリットがある反面, 解析用の形状 モデルを設計に用いるCAD データと別個に作成しなけれ ばならないという課題があった。このため，ともすれば

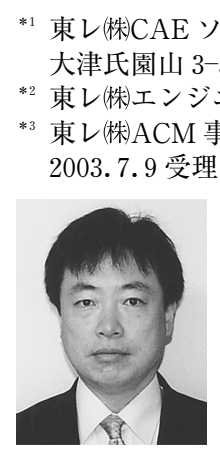

${ }^{* 1}$ Nakano, Ryo

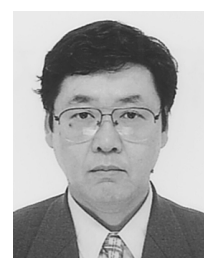

${ }^{* 1}$ Yuki, Takashi

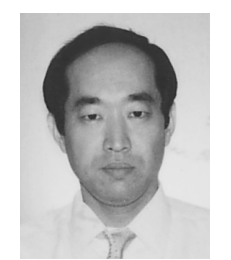

${ }^{* 1}$ Sakaba, Katsuya

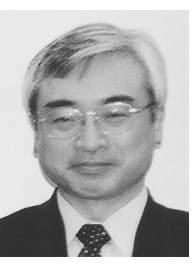

${ }^{*}$ Suga, Yasuo

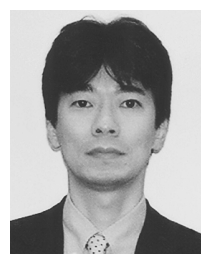

*25awada, Satoshi
$\mathrm{CAE}$ 解析は設計の流れから分離しがちとなり，解析担当 者が懸命にモデルを作成してもすでに開発が進み, 形状変 更されていたという事態も見られた。

今回報告する技術は，射出成形品の設計開発において 3 次元 $\mathrm{CAD}$ と密接に連携し, 3 次元形状を薄肉シェルに変 換することなく，3 次元形状のまま手間をかけずに解析す ることを可能にした技術である。以下，技術開発の狙いと 技術内容，ならびに社内外での活用事例について報告する。

\section{2. 開発の狙い}

射出成形 CAE は図 1 に示すように 2 次元から 3 次元へ 開発が進められてきた. われわれは 2 次元シェル構造モデ ルによる充填〜収縮・そり解析システムの開発から取り組 み, 3 次元システムへの拡張を行った. ここで 3 次元へ拡 張した主な狙いは以下の 3 点である.

1 ）形状モデル二重化の解消による効率化

2) 3 次元形状表現による解析精度の向上

3 ） 3 次元形状の設計検討による製品品質の向上

1）は 3 次元化の最も大きなドライブフォースとなった 点である. 前述のとおり設計開発の流れに乗るためには, どうしてもボトルネックとなる形状モデル作成の手間をな くすことが必要となる.

2）は 3 次元化のもう一つのメリットである. 図 2 に示 すように, 薄肉シェル構造では表現できない段差部や厚肉 部, コーナー部, 分岐部などの 3 次元形状をそのまま表現 できることから, 蓄熱や収縮の局所的なふるまいを正確に 再現することが可能になる。

また，3）は2）とも関連する．例えばコーナー部の R (アール) 形状や肉厚方向のゲート位置など, 3 次元解析 によって 3 次元的な形状設計検討が可能になる.

筆者らは特に 1）の狙いに注目し，3 次元 $\mathrm{CAD}$ データ の品質に関わらず，特別なノウハウも必要とせずに形状 データをほぼ全自動にて作成できる技術の開発を行った。

\begin{tabular}{|c|c|c|c|}
\hline '30 & '70 & '80 & ‘ 00 \\
\hline \multirow[t]{2}{*}{$\begin{array}{l}\text { プラスチック } \\
\text { 射出成形技術 }\end{array}$} & \multirow[t]{2}{*}{$\begin{array}{l}\text { コーネル大CIMP } \\
\text { アーヘン工科大 }\end{array}$} & $\begin{array}{l}\text { 商用ソフト }-->\text { EWS版 } \\
\text { ネットワーク }\end{array}$ & $-\cdots>$ PC版 $-\cdots-\cdots$ \\
\hline & & $\begin{aligned} & 2 \mathrm{D} \text { 展開法--> } \text { FEM } \\
& 2.5 \mathrm{D} \text { 流動解析 } \\
& \vdots \vdots \\
& \text { そり解析 } \\
& \text { 繊維配向解析 }\end{aligned}$ & $\begin{array}{l}->3 D \text { 樹脂流動解析 } \\
\text { 残留応力 } \\
\text { 結晶化シシュレーション }\end{array}$ \\
\hline
\end{tabular}

図 1 射出成形 CAE の変遷 


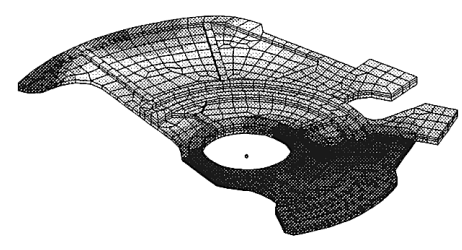

段差を有する機構部品

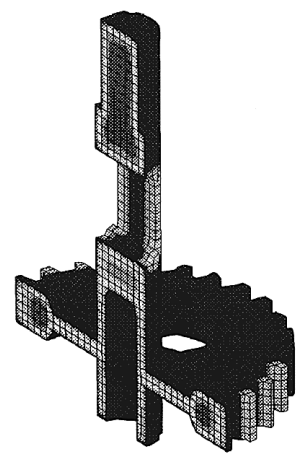

厚肉部を有するギア部品
図 23 次元解析を要する形状の例

また，2，3）に関しては，3 次元解析を行う際に解析実 行者の熟練度や知識に負う所が少なく, 誰が解析しても安 定して精度の良い解が得られるロバストな技術の開発を行 うことを狙ってソルバーの開発を行った. 以下，開発して きた技術内容を述べる。

\section{3 ・メッシュ作成技術}

3 次元解析を実用化するためには，3 次元 CAD とリン クして確実にメッシュを生成しなければならない. 3 次元 $\mathrm{CAD}$ データを利用した数多くの 3 次元自動メッシュソフ トが開発されているが，メッシュ生成手法としては図 3 の ように大別できる.

マップトメッシュ法：メッシュ対象物を 4 角形または 6 面体に分割し,各辺に分割数を定義して節点·要素を生成する。

アドバンシングフロント法：境界上を分割し，その後内 部に向かって節点・要素を生成する.

ボクセルメッシュ法：対象物を包含する領域中に XYZ 軸に平行な走査線を走らせ，格子状のセルを定義し，七ル が対象物に含まれる場合に要素とする.

アドバンシングフロント法は, CAD データがあれば要 素 1 辺の平均的な大きさを入力するだけで, 表面近似精度 の良い 4 面体要素を作成することができる．手間という面 から考えると, もっとも簡単なメッシュ生成方法であるが, 歪んだ要素が生成されたり，4面体要素の作成に関しては, 要素数の制御が困難となる. さらに, 対象形状が少し複雑 （肉厚変化が急激な部分を有するなど）になると, 内部に 向かって要素を発生させていく段階で生成不能となること が多く, 安定したメッシュ作成が難しい。また，CAD デー 夕の品質にも大きく影響されるという課題がある.

マップトメッシュ法は, 表面近似精度, 要素品質に関し て最も優れているが，そのために対象物を 6 面体で分割定 義するといった膨大な手間がかかる.

ボクセルメッシュ法は, 走査線のピッチ間隔を定義する だけで簡単に要素が作成できるが，対象物の表面が階段状 になり，形状の近似精度に課題がある。

著者らは設計・生産の現場で使える射出成形 CAE シス テムという視点から, 多少の不具合がある 3 次元 $\mathrm{CAD}$ データからでも高速にメッシュが作成でき，かつ据れのな い要素が実現されるボクセル法を採用した.

さらに図 4 に示すように形状近似精度の悪さに対応する

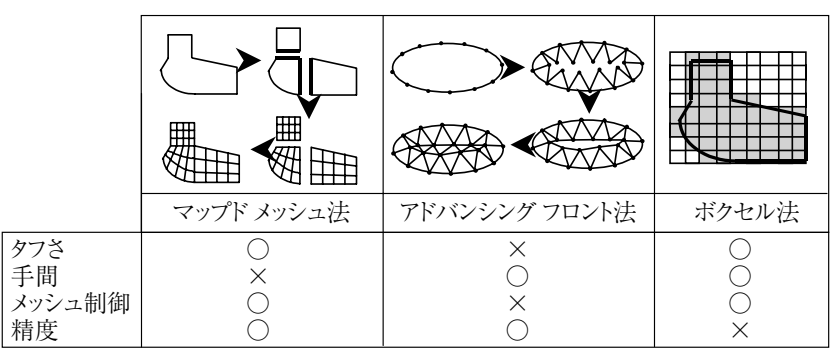

図 3 メッシュ生成方法

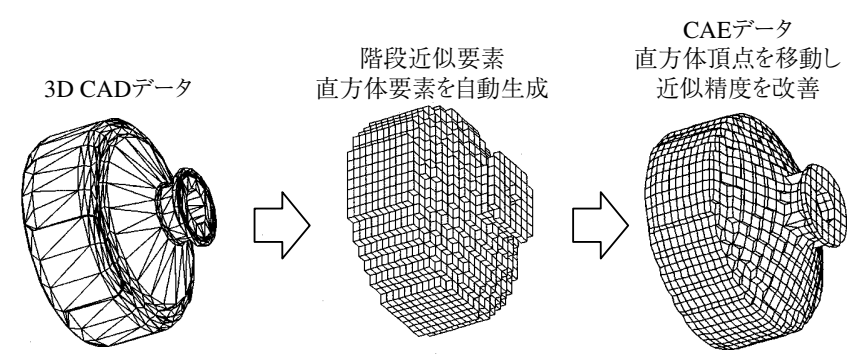

図 4 「3 D TIMON」のメッシュ生成方法

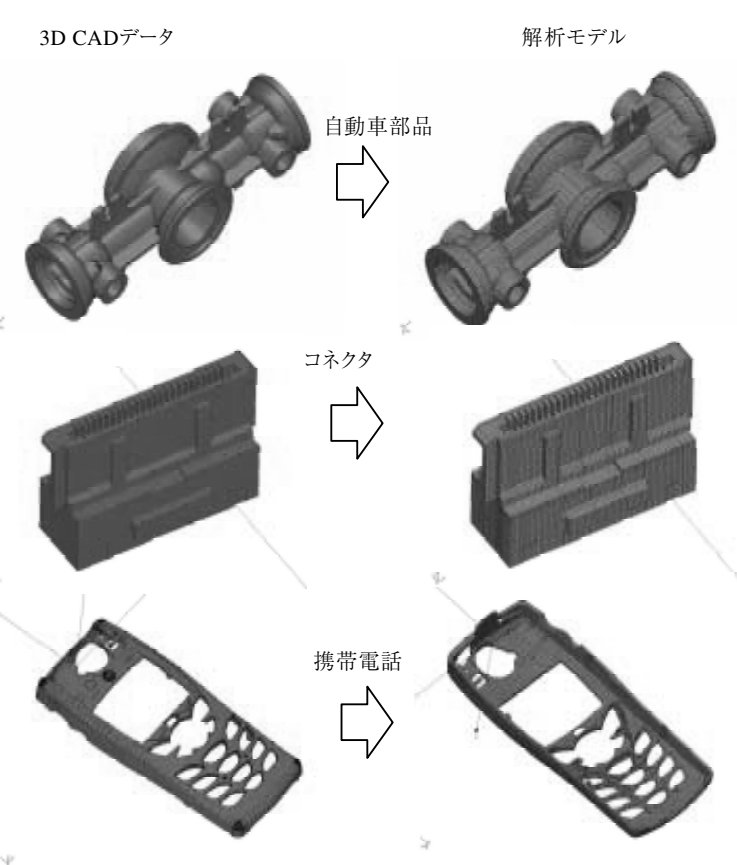

図 5 メッシュ分割例

ため，最外節点を CAD データの表面に移動させる工夫を 施したメッシュ生成技術を開発した。内部節点はラプラシ アンスムージング法により移動し，要素のつぶれを緩和し ている.

2 次元ではモデル化が困難な自動車形状製品, 偏肉部を 有するコネクタ，携帯電話外装部品に対して開発した自動 メッシュモジュールを適用した例を図 5 に示す。形状が複 雑であるため, シェルでモデル化した場合は数日の工数を 必要とする自動車部品に対しても約 6 分でメッシュ作成が 終了し, 実際の解析に取り掛かるまでの工数の大幅な短縮 が実現した。

\section{3 次元ソルバー開発}

3 次元射出成形 CAE では, 樹脂が溶けて・流れて・冷 
却されて・収縮変形する過程をソリッド要素で計算してい く.今回開発したシステムでは, 射出成形プロセスで樹脂 が受ける現象を定常粘性流動, エネルギー保存則, 3 次元 纎維配向方程式, 材料物性複合則などに基づき, コントロー ルボリューム法などを用いて式(1)〜（7)のように定式化さ れている(1),2).

充填解析では，非圧縮・非ニュートン粘性流れを仮定し， ダルシー則に従うポテンシャル流れ（流速の各成分が，そ の方向の圧力勾配に比例する)を用いた。このとき，式(4) により求めた流動コンダクタンス分布を用いる形式に拡張 した.

保圧冷却解析は, 式 (3)をもとに圧縮性を考慮した流体 方程式に拡張し，PVT 状態式を新たに加えた系で，温度・ 圧力・比容積を計算する. 強化繊維の配向解析には, Tucker 式を採用しだ).

ダルシー則

$$
u_{i}=-S \frac{\partial p}{\partial x_{i}}(i=1,2,3)
$$

粘性流動

$$
\frac{\partial P}{\partial x_{i}}=\frac{\partial}{\partial x_{j}}\left(\mu \frac{\partial u_{i}}{\partial x_{j}}\right)
$$

連続の式（非圧縮性）

$$
\frac{\partial u_{i}}{\partial x_{i}}=0
$$

ここに $u_{i}$ は流速成分， $p$ は圧力， $\mu$ は粘度である， $S$ は 流動コンダクタンスであり次式より定める.

$$
\frac{\partial^{2} S}{\partial x_{j} \partial x_{j}}=f\left(\mu, x_{k}\right)
$$

エネルギー保存則

$\rho C_{V} \frac{D T}{D t}=\frac{\partial}{\partial x_{j}}\left(k \frac{\partial T}{\partial x_{j}}\right)+\mu\left(\frac{\partial u_{i}}{\partial x_{j}}+\frac{\partial u_{j}}{\partial x_{i}}\right)^{2}+2 \mu\left(\frac{\partial u_{k}}{\partial x_{k}}\right)^{2}(5)$

ここに $T$ は温度， $k$ は熱伝導率， $C_{V}$ は定積比熱， $t$ は時間 である。

強化短繊維の配向解析では次の Advani and Tuckerの 式年を用いて配向関数の分布を求める.

$$
\begin{aligned}
& \frac{D a_{i j}}{D t}=F\left(\omega, \gamma, C_{I}\right) \\
& a_{i j}=\int P_{i} P_{j} \Psi(P) d P
\end{aligned}
$$

ここに $a_{i j}$ は配向テンソル， $\omega$ は渦度， $\gamma$ は変形速度， $C_{I}$ は干渉係数, $P_{i}$ は繊維方向余弦, $\Psi(P)$ は配向確率密度関 数である.

3 次元化を実用化する上の課題は, 解析時間の増大と計 算の安定性である. 本技術ではこの課題に対して式(1),

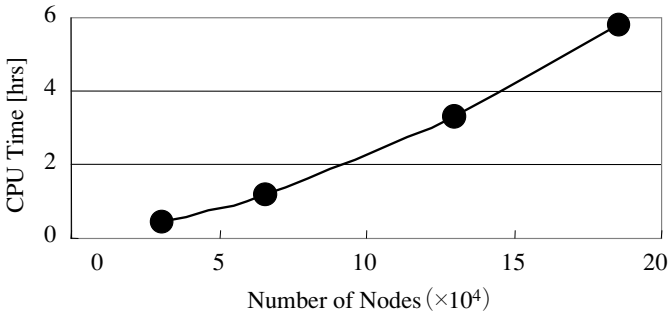

図 6 節点数と解析時間 (PentiumN 1.7 GHz, メモリ $1 \mathrm{~GB}$ )

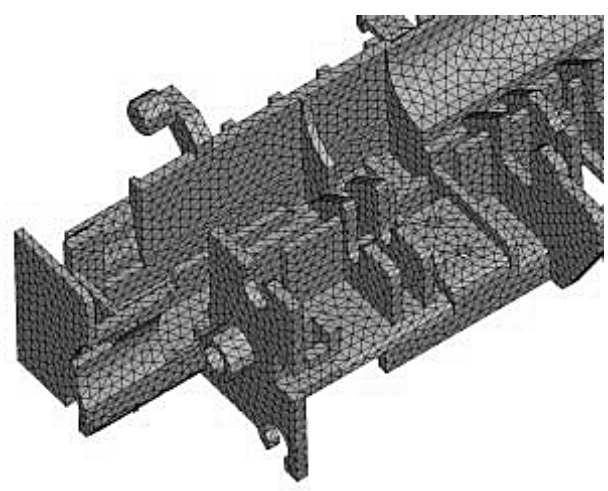

図 7 肉厚方向 1 層ソリッド分割の例

式(4)で表される一般化ダルシー則を開発して適用した. この技術は日・米・欧他で特許化されており，2次元に比 べて自由度が増大する 3 次元解析における高速化と安定性 が実現している.図 6 に PentiumIV $1.7 \mathrm{~GB} /$ メリ $1 \mathrm{~GB}$ での節点数に対する解析時間を示す.

さらに, 本解析技術の特徴として, 図 7 に示すように肉 厚方向に 1 層に分割された 3 次元メッシュ分割に対しても, メッシュを細分割することなく計算可能とした点があげら れる. 通常, 射出成形では温度や粘度など肉厚方向に大き な変化が生じるため, 肉厚方向に多くの計算点を設ける必 要がある. 本解析技術によれば，厚さ方向に 1 層分割が生 じた場合，自動的にシェル要素と同等のコンダクタンスを 与え, 肉厚方向に層分割した 1 次元熱伝導解析 ${ }^{3)}$ 行うこ とによりシェル要素と同等の解析が可能となった.

以上の解析理論に基づき，金型冷却 ${ }^{5}$ ，充填から収縮・ そり変形までを 3 次元で解析可能な射出成形 CAE システ ム「3 D TIMON」を開発した。図 8 に開発したシステム の構成と $\mathrm{I} / \mathrm{O}$ 関係を示す。

\section{5. 適用事例と効果}

\section{1 樹脂ユーザーへの製品開発支援}

当社は樹脂メーカーとしてナイロン, PBT, PPS, POM, LCP といった各種エンプラおよび ABS 樹脂を製造, 販売 しているが，樹脂ユーザーと共同で製品開発を推進するた めに，1983 年より CAE を活用した製品設計，金型設計， 成形条件, 材料選択の最適化, 提案をおこなっている. 最 近では年間 250 件以上の CAE 解析を実施しているが，そ のうち約半数が本技術により開発した 3 次元射出成形 $\mathrm{CAE}$ システム「3 D TIMON」を使用した解析である.

主な解析内容は, ウエルド位置, 射出圧力, 必要型締め 力, 充填バランス, そり変形等を適正化するための製品設 


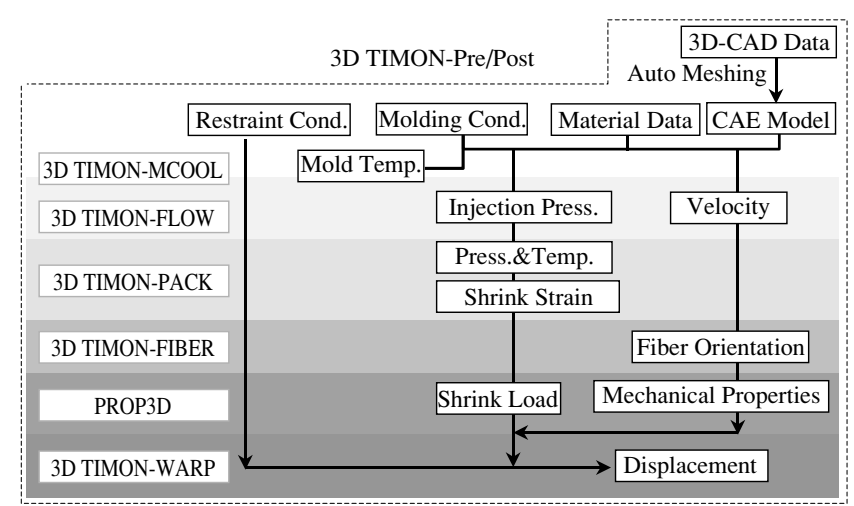

图 $8\lceil 3$ D TIMON」システム構成とデータ I/O

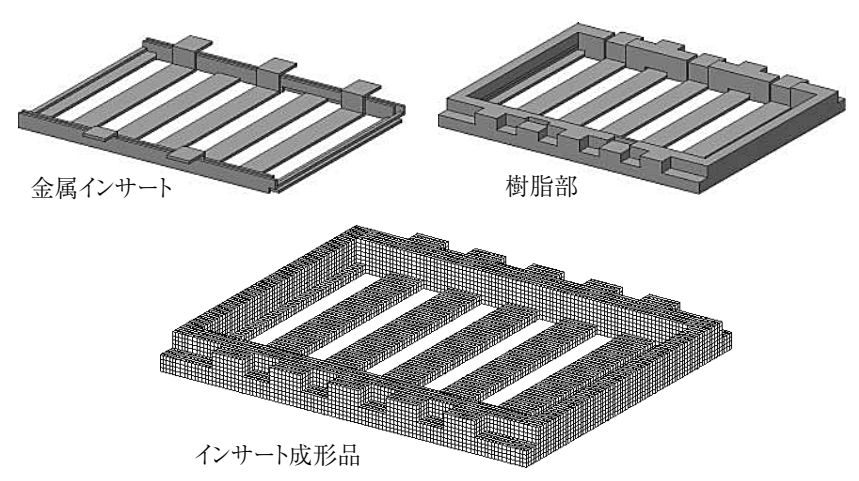

图 9 パワーモジュールの解析モデル

計 (肉厚, リブ等) と金型設計（ゲート，ランナー，冷却 管等）の検討である.また，「3 D TIMON」単体でなく, 構造解析など必要なソフトウェアと組み合わせて, ガラス 纎維配向による機械的物性の異方性を考慮した成形品の熱 変形・熱応力の検討や，インサート成形品のそり変形の検 討も扔こなっている.

本 $3 \mathrm{D}$ 射出 CAE でソリッド要素を使って解析するメ リットとして,メッシュ作成時間の短縮と厚肉形状の忠実 なモデル化による解析精度向上が挙げられる．筆者らは本 $3 \mathrm{D}$ 射出 CAE を用いて解析する場合, 使用する要素 (シェ ル要素, ソリッド要素) は製品形状, 解析内容によって適 宜使い分けている，最近では，開発のスピードアップ，製 品の複雑化 ・高機能化に対応するため, 半数以上の解析で ソリッド要素を用いている.

また，製品の形状設計データの大半は $3 \mathrm{D}$ CAD デー夕 で受け渡しされ，ソリッド要素の利用が増える一因となっ ている. 本 $3 \mathrm{D}$ 射出 CAE では CAD データとしてSTL 形 式ファイルを利用するため, 製品設計に対応した様々な CAD システムを受け手側で準備しなくても，CAD データ の授受がスムーズにできるというメリットもある.

$\lceil 3 \mathrm{D}$ TIMON」の適用事例として, パワーモジュールの そり解析を示す. 図 9 に概略の解析モデルを示す. パワー モジュールは比較的厚肉の金属部品をインサート成形して いる.このようなインサート成形品では, 樹脂と金属の線 膨張差によってそり変形が発生する.

インサート成形品のそり変形を解析によって予測するた めには, ソリッド要素によってインサート金属と樹脂を正 確にモデル化することと, インサート金属の変形も考慮し

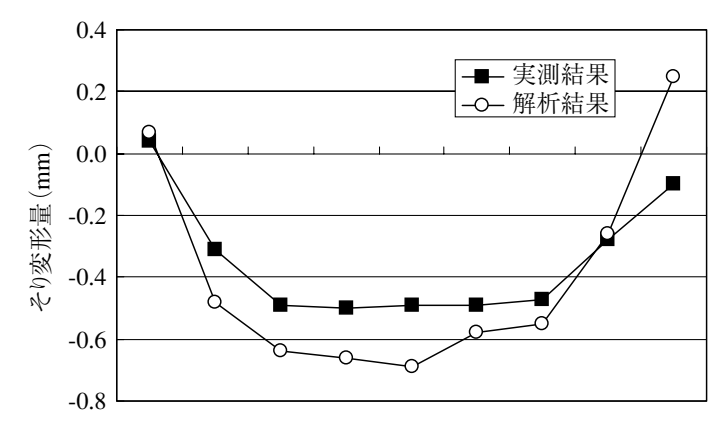

図 10 底面そり変形量の比較

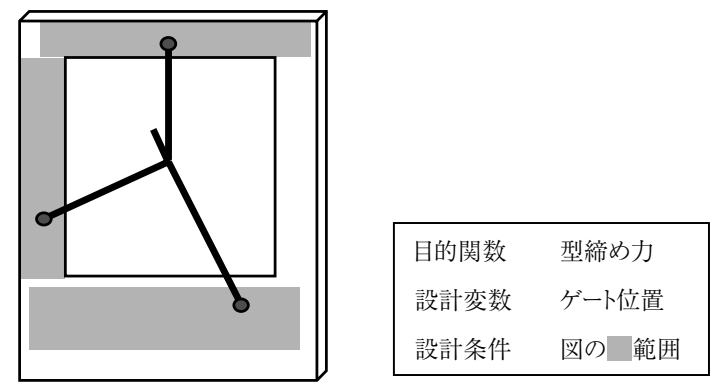

:探索範囲

図 11 筐体のゲート位置最適化による型締め力低減

てそり解析を実行することが必要である。これは本 3 D 射 出 CAE を用いることによって実現された機能である.

図 10 に底面そり変形量の解析結果と実測結果の比較例 を示す．本 $3 \mathrm{D}$ 射出 CAE を用いてインサート金属を考慮 したそり変形解析を抢こなうことによって，そり変形量の 予測值は実測結果とほほ一致した。また，そり対策案を本 $3 \mathrm{D}$ 射出 $\mathrm{CAE}$ で検討して, ゲート点数や成形品形状を変 更することにより，そり変形量スペックを満足することが できた。

また, 図 11 は電子機器筐体に対して型締め力の低減を 目的としてゲート位置の最適化を行った例である。最適化 計算エンジンとしては”iSIGHT”用い，本 $3 \mathrm{D}$ 射出 CAE と組み合わせて図 12 に示す最適化システムを構築した。 ゲート位置は図 11 の網ふせ部分の範囲で変更したが, 当 該範囲内の FEM メッシュ上の既存節点をゲートとするこ ととした. したがって設計変数が離散值となることから,最 適化手法として遺伝的アルゴリズムを用いた。自動最適化 計算には 43 時間を要し, 結果として型締め力を約 $1 / 2$ に 低減するゲート位置最適解が得られた。このような最適化 計算はそり量低隇やウエルド位置制御等にも活用している.

\section{2 社外ユーザーによる活用状況}

現在, 本 $3 \mathrm{D}$ 射出 $\mathrm{CAE}$ ソフトウェアのユーザーの分野 としては, 自動車, 家電 $\mathrm{OA}$, 電気電子部品, その他に大 別され, 国内約 120 社に扔いてライセンスが稼㗢している. 主な利用者の業務と活用内容について, 表 1 に示す。

表 1 に示すように, 研究, 生産技術, 型設計, 製品設計 とそれぞれ活用するシチュエーションに応じて活用の目的 と内容が異なってくる. CAE をエンジニアリングッール として活用し成果を上げていくために，それぞれの目的に 応じた使いこなし（例えば入力データの品質管理や出力の 解釈など）が工夫されている. 


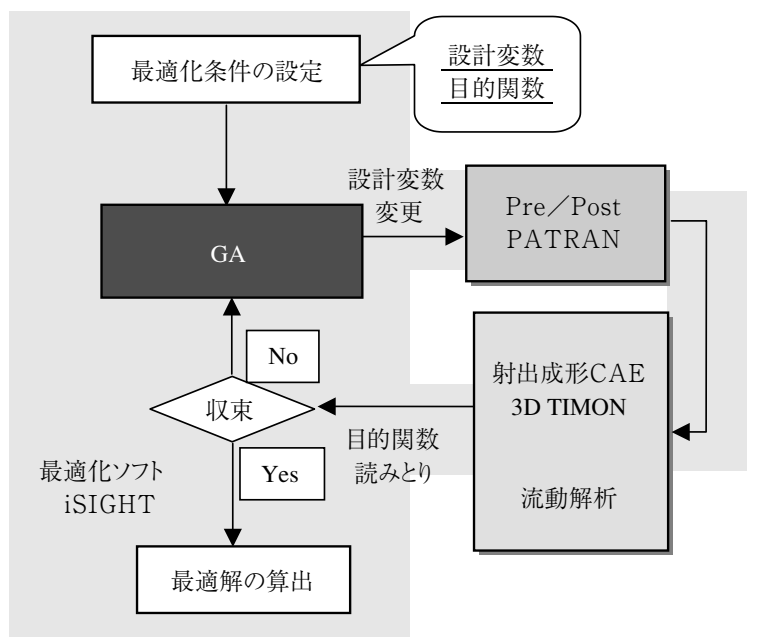

図 12 ゲート位置最適化システムの構成

このように，製品設計や生産技術などそれぞれの利用者 が検討，検証を実施することによって，例えば表 2 に示す ような効果を上げることが期待できる。

具体的な活用事例を表 3 に示す. CAE と他の対策を組

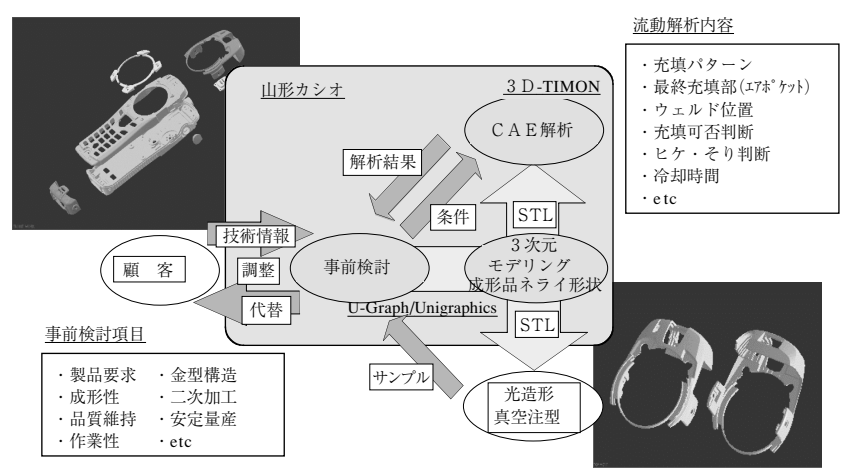

図 133 次元モデリングをべースとした製品開発システム 例 (山形カシオ株式会社, 型技術, ’02, 5 月号より)

み合わせた結果，サイクルタイムの短縮などにより，大幅 なコストダウン効果が得られている.

図 13 に 3 次元 CAD で作成された STL データをベース とした製品開発システムの構築例を示す ${ }^{5)}$.この例では, STL データをもとにラピッドプロトタイピングによる形 状確認と, CAE 解析による成形性の確認を同時に行って いる.さらにこれらの 3 次元データを用いることにより,

表 1 「3 D TIMON」の活用ユーザーと活用内容

\begin{tabular}{|c|c|c|}
\hline CAE の活用ユーザー & 目的 & 活用内容 \\
\hline $\begin{array}{l}\text { 生産技術研究者 } \\
\text { (金型内可視化ツール) }\end{array}$ & $\begin{array}{l}\text { 不良原因の究明 } \\
\text { 新規成形法の研究 }\end{array}$ & $\begin{array}{l}\text { そり, ヒケ不良原因と対策立案 } \\
\text { 射出圧縮, インサート成形などの可能性検討 }\end{array}$ \\
\hline $\begin{array}{l}\text { 生産技術者 } \\
\text { (品質管理・改善支援ツール) }\end{array}$ & $\begin{array}{l}\text { 金型方案の初期検討 } \\
\text { 生産コスト見積り } \\
\text { 金型手配チェック } \\
\text { 成形不良対策 }\end{array}$ & $\begin{array}{l}\text { ショートショット, ウェルドライン，ゲート位置 } \\
\text { 成形機サイズ (型締め力予測), サイクルタイム推定 } \\
\text { 充填不良, ガス焼け, ウェルドライン, バリ } \\
\text { ウェルドライン, ヒケ, そり }\end{array}$ \\
\hline $\begin{array}{l}\text { 金型設計者 } \\
\text { (金型設計支援ツール) }\end{array}$ & $\begin{array}{l}\text { 冷却配管の検討 } \\
\text { 多数個取り検討 } \\
\text { 成形不良の予測 }\end{array}$ & $\begin{array}{l}\text { 金型温度分布の予測及び制御, 熱溜まりの有無 } \\
\text { ランナーバランス, キャビティ配置 } \\
\text { ガスベント位置, ヒケに関するチェック, そり傾向の把握 }\end{array}$ \\
\hline $\begin{array}{l}\text { 製品設計者 } \\
\text { (形状決定支援ツール) }\end{array}$ & $\begin{array}{l}\text { 製品形状の検証 } \\
\text { 他の FEM 連携 }\end{array}$ & $\begin{array}{l}\text { 充填圧力と肉厚の相関関係, リブ厚み, 配置とそり変形 } \\
\text { 繊維配向, そり, 初期歪みを想定した解析 }\end{array}$ \\
\hline
\end{tabular}

表 $2\lceil 3$ D TIMON」の適用効果

\begin{tabular}{|c|c|}
\hline $\mathrm{CAE}$ 適用効果 & 内 \\
\hline $\begin{array}{l}\text { 製品設計上のミス防止 } \\
\text { (設計変更チェック) }\end{array}$ & 充填不良, ウェルド位置, ヒケ発生の予測と改善 \\
\hline $\begin{array}{l}\text { 製品コストの削減 } \\
\text { (サイクル短縮，成形機ダウンサイジング) }\end{array}$ & $\begin{array}{l}\text { 熱溜り予測, 製品肉厚やランナ径の適正化の実施 } \\
\text { ゲート位置，フローリーダの検討による射出圧力低減 }\end{array}$ \\
\hline $\begin{array}{l}\text { 金型コストの削減 } \\
\text { (設計・製作ノウハウの確立) }\end{array}$ & $\begin{array}{l}\text { ヒケ, 外観不良などの事前予測などの実施 } \\
\text { ゲート位置, 径の検討, 金型ダウンサイジング }\end{array}$ \\
\hline $\begin{array}{l}\text { 開発期間短縮 } \\
\text { (トライ回数の削減) }\end{array}$ & 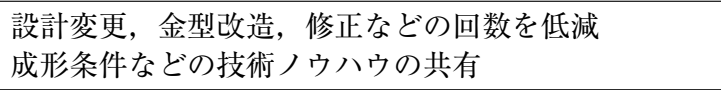 \\
\hline エンドユーザーの説得ツール & 形状変更の必要性などのプレゼン・ツール \\
\hline
\end{tabular}

表 $3\lceil 3$ D TIMON」の適用例

\begin{tabular}{|c|c|c|c|}
\hline 品 & 的 & 内 & 効 \\
\hline 携帯電話筐体 & 成形サイクル短縮 & 肉厚，ゲート配置，ランナー径適正化 & サイクル 40\% 減 \\
\hline クリーナ筐体 & 成形サイクル短縮 & 熱溜り予測による冷却管配置見直し & サイクル 30\% 減 \\
\hline 自動車カウルグリル & 型締め力低減 ～ & ファミリー取りのランナーバランス改善 & 型締め $35 \%$ 減 \\
\hline ハウジング部品 & 製品，金型コストの低減 & ゲート数削減 & $\begin{array}{l}3 \text { プレート } 5 \text { 点ゲート } \\
2 \text { プレート } 1 \text { 点ゲート }\end{array}$ \\
\hline 一般 & 平均トライ回数削減 & 新規製品への「3 D TIMON」適用 & 平均トライ回数を $1 / 3$ へ \\
\hline
\end{tabular}


上流側顧客と事前に詳細な設計検討を行うことが可能とな り，手戻りの少ない効率的な製品開発を実現している.

\section{6. 今後の開発方針}

以上，筆者らの開発してきた 3 次元射出成形 CAE シス テムの技術内容と活用事例を報告した. 今後の開発方針と して, 筆者らはさらに以下のような展開を検討している.

1）収縮・そり解析精度の向上

2）より簡便・高速なシステムへの進化

3 ）評価ノウハウ組込みによる実用性の向上

1）射出成形 CAE の精度は 3 次元化によって一つのス テップを上がることはできたが，計算容量の限界からくる 解像度の問題などのため, 常に十分な実用精度が得られる とは言い難い。特に収縮・そり解析に関して定性的評価の 域を出ないことが多く, 解析アルゴリズムだけでなく, 樹 脂データの取扱い, 形状モデル, 射出条件の入力方法など も含め, 精度向上を検討していく.

一方で，2）簡便化, 高速化の要求はとどまるところを 知らない. 特に設計検討を行う場合，短い開発期間の間に 多数の条件変更を解析するためにもっと早く, もっと簡単 に間違いなく解析できることが要求され, 絶え間ない技術 開発が必要となっている. 3 次元化による解析自由度数の 増加と, 自動最適化計算などによる解析ケース数の増加が 今後も課題になるものと考えられる.

3）はCAE解析結果からいかにして成形不良を事前に 察知し，的確な対策を打つかという技術であり，CAE 導 入の効果を出せるか否かがここにかかっている. 個々の問
題解決に対する蓄積を進め，システムとして具現化するこ とを今後検討したい.

\section{7. と め}

3 次元 $\mathrm{CAD}$ データを基本とする 3 次元設計の普及を背 景として, 筆者らは 3 次元デー夕を活用して効率的, かつ 高精度に設計検討を行うことができる 3 次元 CAE 技術を 開発した。

本稿にて報告した 3 次元射出成形 CAE システムは「3 D TIMON」として市販され, 約 120 社で日々の設計開発 業務に活用されている。 また，筆者ら自身も年間 100 件以 上の製品開発に社内活用し，成形不良低減のための金型設 計検討などを実施して効果を上げている.

このように, 3 次元 $\mathrm{CAE}$ の活用は今後も進んでいくも のと考えられる. 今後, さらに収縮・そり解析精度の改善 や簡便性・高速化の追求，実用性の向上を図り，樹脂製品 設計, 金型設計の競争力強化への一助となることを願って いる.

\section{参 考 文 献}

1 ）坂場, 中野, 田中：成形加工, 10(5) (1998)

2 ) Nakano, R. and Tanaka, T. : PPS-14, 321 (1998)

3 ) 岡田, 速水, 中野：成形加工シンポジア， 75 (2002)

4) Advani, G. and Tucker III, L. : J. Rheology, 31 (8), 751 (1987)

5 ）大井：成形加工， 14(9)，566(2002)

6 ）高谷：型技術， 16(6)，55(2001) 